Tarih Kültür ve Sanat Araştırmaları Dergisi

Revue des Recherches en Histoire Culture et Art

مجلة البحوث التاريخية والثقافية والفنية
Vol. 6, No. 4, September 2017

Copyright (C) Karabuk University

http://kutaksam.karabuk.edu.tr

\title{
DOI: 10.7596/taksad.v6i4.1119
}

Citation: Kamalieva, R., Ibragimov, M., Galimullina, A., \& Nickolsky, E. (2017). The Image of the Garden in the Creativity of Ravil Bukharaev and Lydia Grigorieva in the Context of Dialogue of Cultures. Journal of History Culture and Art Research, 6(4), 1063-1070. doi:http://dx.doi.org/10.7596/taksad.v6i4.1119

\section{The Image of the Garden in the Creativity of Ravil Bukharaev and Lydia Grigorieva in the Context of Dialogue of Cultures}

\author{
Regina R. Kamalieva ${ }^{1}$, Marsel I. Ibragimov ${ }^{2}$ \\ Alfiya F. Galimullina ${ }^{3}$, Evgeny V. Nickolsky ${ }^{4}$
}

\begin{abstract}
One of the research aspects in this direction is considered in this article: the question of semantic and functional features of the garden image in Ravil Bukharayev and Lydia Grigorieva's poetry. The concept of dialogue of cultures which allows considering the garden image in Bukharayev and Grigorieva's poetry in the aspect of semiosis and broad inter-textual communications including various texts and cultural codes which are present in them became the basis of this research. Having considered specifics of artistic realization of the garden image in Bukharayev and Grigorieva's creativity authors of article came to the following conclusions: there are essential differences in attitudes of the poets reflected in their art creativity. If for R. Bukharayev the image of a garden as a rule is associated with the homeland, the native language from which isolation is sharply experienced by the poet (in the cycles "Kazan Snow", "Agony in the Garden", etc.), then Grigorieva organically fits into the English literary environment, its acceptance of the English world, cultures occurs without visible efforts, is harmonious and creative. Grigorieva learns philosophy of garden not only by means of traditional poetic means of expression, but also creating and proving the new synthetic genre determined by it as "film poetry", "photo poetry".
\end{abstract}

Keywords: Russian poetry, Russian-speaking literature, Cultural codes, Mytheme, Dialogue of cultures, Plurality of identifications, Ravil Bukharayev, National identity, Author consciousness, Lydia Grigorieva.

\footnotetext{
${ }^{1}$ Kazan Federal University, Leo Tolstoy Institute of Philology and Intercultural Communication. E-mail: kamalievar@list.ru

${ }^{2}$ Kazan Federal (Volga Region) University, Leo Tolstoy Institute of Philology and Intercultural Communication.

${ }^{3}$ Kazan Federal University, Leo Tolstoy Institute of Philology and Intercultural Communication.

${ }^{4}$ Warsaw University, Department of History of Russian Literature, Institute of Russian Studies, Poland.
} 


\section{Introduction}

In Ravil Bukharayev and Lydia Grigorieva's creativity the principle of plurality of cultures and discourses was brightly shown. The poetic cycles "Agony in the Garden" can become examples of manifestation of plurality of identifications in the work of art (1989 - 1991, "The Kazan snow" (1968 - 1974) R. Bukharayev and the collection "Gardens Terrestrial and Heavenly" (2017) L. Grigorieva).

The subject of the person garden, judgment of the place of the person, creative person in society, searches of the place unite R. Bukharayev's poems in lives "Omaroman", "Nichayev in Altai", "Around Tuqay", "Time of flowers". The embodiment of an eternal dream of eternally unattainable Paradise - the Garden is the poem "Omaroman".

The lyrical hero of R. Bukharayev is far from the homeland and sharply feels the loneliness, and in this regard paints such simple, imperceptible details in usual life as "a smoke coming from a pipe", "began to smell lands" are close to it, "apple, one in the whole garden", "there is neither house, nor a garden, nor me", "to inhale a smell of an early leaf / currant - from an evening bush ...", "a garden kitchen garden and the wooden house / and an oven with redblue fire ..." (Bukharayev, 2011: 340). The image of a garden strengthened by threefold denial aggravates feeling of tragic loneliness of the lyrical hero.

Reflections of the poet lead to tragic understanding that loss of the homeland, language, national values, eventually, leads to loss of the identity, so, and to spiritual disappearance. Especially sharply tragic feeling of loss of communication with Kazan, the homeland is embodied in the cycles "Alms of the Native Language" (a wreath of crude smoke) and "The Kazan snow" in which the image of the city of the childhood, "a grandmother's garden" "Paradise Lost" is created. Plurality of identifications is shown in R. Bukharayev's cycle "Agony in the Garden" as dialogical combination of the cultural codes which are going back to different traditions: Christian, Muslim, Soviet, the codes connected with traditions of the Russian and east literatures.

Lydia Grigorieva's collection "Gardens terrestrial and heavenly" crowns the garden image of Soul which always with the lyrical heroine, penetrates optimistic attitude all her creativity, allows to feel harmoniously everywhere: both in England, and in Russia: "To leave in a garden, it is not necessary and to try: / There the worlds are multiplied, flowers propagate, / clusters star, heavy there, grow ripe, / And the Lord from heaven despises them" (Grigorieva, 2017: 53). For Grigorieva the garden becomes a criterion of everything including poetry. Not incidentally, she used the hobby for the photo for creation of a synthetic genre - photo poetry. 
Thus, in R. Bukharayev's creativity the image of a garden is steadily connected with a subject of the lost homeland, the native language, motive of a spiritual orphanhood, and in L. Grigorieva's creativity in the image of a garden there is no tragedy, there is no feeling of isolation from the homeland, mysteriousness of the Russian soul, its openness to the world, other cultures is more emphasized here.

\section{Materials and methods}

Since the end of last century interest in Russian-speaking literature increases in domestic literary criticism. In the researches devoted to this phenomenon its place and a role in the history of national literatures are defined. In parallel there is a search new, other than the created during the Soviet period, methodological approaches to Russian-speaking literature. So, certain researchers consider Russian-speaking literature from the point of view of a new phenomenological paradigm, "which proceeds from a worthiness and uniqueness of the studied phenomena, complexity and multi-facturalism of their genesis" (Lagunova, 2005: 15).

Besides phenomenological approach to Russian-speaking literature, modern researchers offer the dialogical, based on M. M. Bakhtin's ideas (Leyderman, 2005). The possibility of connection of phenomenological and dialogical approaches, in particular, can be shown on the example of works of modern poets R. Bukharayev and L. Grigorieva.

In modern researches various types of consciousness, the identifications caused by plurality, are analyzed by literature (Safiullin, 2010; Amineva, 2015; Zagidullina \& Amineva, 2016; Vasilyev, 2003). Philosophical justification of plurality of identifications is the modern philosophy (J. Derrida, M. Foucault, J. Delez, F. Gvattari, etc.) approving a plurality priority over unity, distinctions over identity (Delez, 1998; Derrida, 2000). Cross-cultural approaches which effectiveness is revealed in a number of domestic (Khabibullina \& Zinnatullina, 2016; Safin et al., 2015; Safonova \& Erofeeva, 2016; Yusupova et al., 2015) and foreign researches (Berry, 1999; Kristeva, 1980; Genette, 1982) exerted impact on the choice of methods of our research.

The basis of a research was made by historical, functional, and comparative approaches to consideration of specifics of the embodiment of the garden image in R. Bukharayev and L. Grigorieva's creativity in the context of dialogue of cultures.

\section{Results and discussion}

Works of the poet Ravil Bukharayev - are one of examples of plurality of the identifications in literature. Bukharayev wrote in several languages: Russian, Hungarian, English, Tatar become key concepts in the writer's reflections about identity "I" and "others". To understand, 
experience "others" (foreign language, culture, literature), according to R. Bukharayev, it is possible, having only made it the: "But that's piece that / it is only impossible to look at one language outside, calibrating it unless with own speech / to understand and comprehend - it is necessary to enter this garden / and to hear the intimate music of leaves from the outside sounding strange / and at times and it is ridiculous" (Bukharayev, 2001: 14).

The principle of plurality of cultures and discourses is embodied in poetics of the cycles "Agony in the Garden" and "Kazan Snow" of R. Bukharayev. The text of poems of the cycle "Agony in the Garden" is sated with the numerous hints and reminiscences sending the reader to different cultures. So, in the poem "Tripod" is a book "About Imitation Christ" of Foma Kempiysky (the lyrical hero correlates this book to "Islam truth", in "Garden" - Christian and Muslim images (Dadzhal, Jesus, the Star of Bethlehem). The text included sayings from the Koran in the Arab language (their translation into Russian is given by R. Bukharayev in footnotes). The beginning of the poem "Well" is remarkable: "When he wants to come back to the Garden, / he whispers in Arab: "A sack to an aguz ... / min. Shari hasadin Iza Hasad" ..." (Bukharayev, 2011: 106). In the quoted poem connect religious (saying from the Koran and a mention of the orthodox theologian - John Chrisos), political (the politburo, Karabakh) and Soviet (Ekibastuz, "the happy childhood") discourses.

Symbolical and mythological images also send the reader to different cultures. The image symbol of a bowl which is taken out in the title of a cycle - to the Gospel ("Agony in the Garden") and corpus, going back to an evangelical plot, in particular, to the poem "Hamlet" from the cycle "Yury Zhivago's Poems" B. Parsnip. A garden symbol - to evangelical Garden of Gethsemane, a well - to a sufia and to the poet Hodge-Ahmed Yassavi, who having reached sixty three years, began to live in an earth hole because he did not want to go on the ground longer than the Saint Prophet of Islam. At the same time, refracting in consciousness of the lyrical hero, these images gain individual value. With their help the author creates internal space of the lyrical hero which is opposed to the outside world. This opposition of internal and external is demonstrated in the poem "Garden": "I spent the night in the mosque Yassavi / in Frankfurt am Main, near the station, / in a quarter of paid blue love. / At night chestnuts blossomed. Whose power over the world until the end of Times / Sacred Scripture predicted an eye of Dazzala, / looked in a window: neon - / advertising of vegetable marrows, billiard, porno/color show-windows sparkled; the accordion / from nostalgia sobbed, but also it is foolish, - / I will tell, - to sight closely in the dark, / but to outlook - it is spacious" (Bukharayev, 2011: 101). The lyrical hero opposes to sight (external) outlook (internal). For it the internal support allowing keeping identity are extremely significant. In the world of 
plurality (cultures, religions, political systems, languages) for the lyrical hero it is important to keep unity. First of all, this is unity of God.

One more noticeable feature of existential structure of a cycle - is a ratio of static and dynamic chronotopes. In the majority of poems time and space are static: in such poems, as a rule, in the center there are landscape images beheld by the lyrical hero. In the cycle "Kazan Snow" the image of the city of the childhood, "a grandmother's garden" - "Paradise Lost" is created. The motive of the lost paradise garden especially bitterly sounds in the second sonnet of a cycle and contacts image of the Tatar grandmother and the fairy tales told by her in the childhood: "Mute, memory is betrayed a hundred times; / in darkness sad light of a window dies away; / alone wet garden sighs; / dogs howl - the punks wander to light".

In the fourth sonnet the lost district-garden of the native language, the homeland is found by the lyrical hero in a dream: Whether "Sacred unselfishness will return back sometime/? For now / I close eyes - I see: a white garden, over a flock of apple-trees clouds shine. / Flowers die away, again burn, / the shadow of clouds is transparent and easy... / it is a pity, a barren flower which year in a row, / the garden of apples will not give us for certain".

In this regard perception by Lydia Grigorieva of Kazan is interesting. Which the poetess embodies in the poem "When I See the Garden Blossoming ..." (Kazan, 1969) in the image of "gardens" opposed to an image of "cherry orchard" from the childhood. It is possible to appear in it only in dreams of the lyrical heroine. The motive of a dream helps to reach idyll again, to return the lost paradise of the childhood where still the beloved grandfather is living and the cherry orchard blossoms: "And at night noise industrial / at the windows of a narrow bedroom. / And dream, semi-nonsense (...). / among cherry the grandfather costs trees. / I call him, the mute townswoman, / and I wake up. / bitterly to me and hot" (Grigorieva, 2017: 27).

However the reality is unfavorable therefore "bitterly and hot", others city and the small homeland, rural idyll is opposed to the lyrical heroine here, in this context gets the new negative shade the word "city" repeated at the end of the poem "I call him, the mute townswoman": "On a small garden city / I as the peasant poor, / I Look with envious melancholy" (Grigorieva, 2017: 27).

The feeling of a disharmony of the city is inherent not only in relation to Kazan, and in general to any city, as to unfreedom space: "How many for winter of heat in me accumulated, / and where to put it, tell on favor? / In this city of neither a tree, nor a garden. / Again to heart to become empty as to the street at midnight, / where wind and "ambulance" (1971) rushes. 
In Grigorieva's poetry the garden gains symbolical value as a symbol of happy harmonious life, it loses real outlines, turning into "a star garden", guarantee of optimism and happiness: "It is green around. Perfectly. / Leaves mature ring. / over my melancholy vain / the star garden Hangs. / Rose rises, blossoming, / the Garden ruddy, painted! / over my anguish / Wind rushes through" (Grigorieva, 2017: 41).

The image of a garden became keynote for Grigorieva's creativity and names of collections of her poems confirm this, for example: "A May garden" (1981), "Grape light" (1984), "The mad gardener" (1999), "Education of a garden" (2001), "A dream in gardens - verses of the 21st century" (2009).

In poetry and in general in Grigorieva's creativity the image of a garden appears in the first and principal value - paradise created by God, the place where the lyrical heroine finds harmony, feels the security from this hostile world, this place where she can create beauty and harmony.

Lydia Grigorieva's poetry organically fits also into a context of modern English poetry. It is promoted also by a keynote subject of a garden in her creativity. It is known that in the English literature the relation to a garden - an important marker of "Englishness" in the art text.

\section{Conclusion}

Plurality of identifications acts as one of the art principles in R. Bukharayev's cycles "Agony in the Garden" and "The Kazan snow", being shown as plurality of cultural and literary codes. At the level of author's consciousness plurality of identifications acts as plurality of types of consciousness: religious, civil, poetic. The analysis of artistic realization of an image of gardens, along with the analysis of other components of poetics (first of all - the subject sphere) is one of "keys" to understanding of identity in R. Bukharayev's poetry.

Grigorieva's I - is a deeply believing person therefore she perceives a garden in a complex of Christian symbolics. By recognition of the poetess made in the forward to the book "Gardens terrestrial and heavenly": "The garden is a God's prototype of the world. The garden is a sign concept. Garden philosophy. Garden mystery. The star sky is the garden cultivated by the Lord too (...) And the person - is the gardener" (Grigorieva, 2017: 7). The poetess, as well as her lyrical heroine, remaining the orthodox Christian, it is open to perception of beauty in any culture, at any people of the world.

L. Grigorieva continues a subject of "a star garden" in the poem "Flying Pack of Gardens" (1999, London) in which the metaphorical image "flying pack of gardens" is created, 
developing a subject of a way, a wandering: "... The garden with mysterious Russian soul, / But increased in the foreign land the stranger ... (...) / Got lost between stars, without having left marks, / Flying pack of gardens ..." (Grigorieva, 2017: 43).

In the garden image of Lydia Grigorieva there is no tragedy, there is no feeling of isolation from the native land, the homeland, mysteriousness of the Russian soul is more emphasized here: garden "into the earth grew, grew up, got used, / Responded to Russian ...", "garden with mysterious Russian soul, / But increased in the foreign land the stranger...", "humored, gave to drink with interest, / But to it a wish arose home". The garden became flying not because of some external negative circumstances but because "he wanted home". So, in the poem there is an image of the House homeland in which the person aspires not because that to it there in the foreign land is bad but because it is his homeland, having only found which the person can be really happy. Such interpretation of an image of the House homeland, gardens unites in many respects opposite attitude of two modern poets - R. Bukharayev and L. Grigorieva.

\section{Acknowledgements}

Research is performed according to the Russian Government Program of Competitive Growth of Kazan Federal University.

\section{References}

Amineva, V. R. (2015). Phenomenon of border in interliterary dialogues. Journal of language and literature, ISSN: 2078-0303, 6(2), 246-249.

Berry, E. \& Epstein, M. (1999). Transcultural Experiments: Russian and American Models of Creative Communication. New York: St. Martin's Press.

Bukharayev, R. (2001). Infinite train: Chosen verses and poems. Kazan: Magarif.

Bukharayev, R. (2011). Chosen works: Book of verses. Kazan: Magarif.

Bukharayev, R. (2004). The Kazan snow - Verses. Kazan: Magarif.

Delez, J. (1998). Distinction and repetition. SPb.: Petropolis.

Derrida, J. (2000). Letter and distinction. SPb.: Gumanit Academic Project agency. 
Genette, G. (1982). Palimpsestes, La littérature au second degré. Paris: Seuil.

Grigorieva, L. N. (2017). Gardens terrestrial and heavenly. SPb.: Alateya.

Khabibullina, L. \& Zinnatullina, Z. (2016). The role of historical and religious components in John Fowles's novel a maggot. Pertanika Journal of Social Sciences and Humanities, 24(2), 767-776.

Kristeva, J. (1980). Desire in Language: A Semiotic Approach to Literature and Art. New York: Columbia University Press.

Lagunova, O. K. (2005). Phenomenon of works of Russian-speaking writers of Nenets and Khanty of the last third of the 20th century. Avtoref. Thesis Art Sci PhD. M.

Leyderman, N. L. (2005). Russian-speaking literature - the intersection of cultures. The Russian literature of the XX-XXI centuries: directions and currents, Yekaterinburg, 8, 48-59.

Safin, I. K.; Kolosova, E. I. \& Bychkova, T. A. (2015). Representation of gender concepts in the Russian and Polish languages. Social Sciences, 10(5), 562-565.

Safiullin, Y. G. (2010). Plurality of literatures. Theory of literature: the dictionary for students. Kazan: Kazan un-t.

Safonova, S. G. \& Erofeeva, I. V. (2016). Representation of a concept "Good" in a language picture of the Middle Ages world (on chronicles data). Journal of Language and Literature, ISSN: 2078-0303, 7(3), 269-271.

Vasilyev, N. L. (2003). Historicism and relativity of a concept "national literature". Comparative literary criticism: theoretical and historical aspects: Materials of the International scientific conference "Comparative Literary Criticism" (V Pospelovsky readings), pp. 53-59. M.: MSU publishing house.

Yusupova, Z. F.; Shakurova, M. M.; Saygushev, N. Y.; Vedeneeva, O. A. \& Kashina, S. C. (2016). Managerial tools of academic knowledge formation process. International Review of Management and Marketing, 6(2), 403-409.

Zagidullina, D. \& Amineva, V. (2016). Avant-Garde Research in the Field of Verse Forms. XLinguae European Scientific Language Journal, 9(1), 135 - 145. 